\title{
Effects of improved glycaemic control on calcium and magnesium homeostasis in type II diabetes
}

\author{
A M McBAIN, I R F BROWN, D G MENZIES, * I W CAMPBELL* \\ From the Department of Clinical Chemistry, Fife Area Laboratory, and the *Diabetic Department, Victoria \\ Hospital, Kirkcaldy, Scotland
}

SUMMARY Poorly controlled type II diabetic patients with hypomagnesaemia, hypermagnesuria, and hypercalciuria were allocated to treatment with either metformin or glipizide, to determine the effects on some indices of mineral metabolism. Despite comparable improvement in glycaemic control, assessed by glucose and haemoglobin $\mathbf{A}_{1}$, there were significant differences between the two groups in the handling of magnesium. Patients receiving metformin showed a reduction in magnesium excretion but remained hypomagnesaemic and hypercalciuric. In contrast, patients receiving glipizide exhibited little change in either magnesium or calcium excretion but showed a significant rise in serum magnesium.

Although it has been known for some time that diabetes mellitus is associated with osteopenia, the pathogenesis of this generalised decrease in bone mass is still not clear. Increased urinary excretion of calcium, phosphate, and magnesium concentrations has been observed in both type I and type II diabetes, particularly if poorly controlled..$^{1-3}$ This mineral loss has been attributed to several factors and in particular to glycosuria, but a whole range of metabolic changes including chronic acidosis, insulin deficiency, impaired parathormone action, and changed vitamin $D$ metabolism could be implicated. ${ }^{4}$ Although there is no consistent evidence that this loss is associated with changes in serum phosphate or in the serum calcium fractions, there have been several reports indicating that hypomagnesaemia is commonly found in diabetics. 5 The importance of this observation in relation to total body and soft tissue stores of magnesium is not clear, ${ }^{8}$ but it may be of some clinical value as hypomagnesaemia has been suggested as a risk factor for the development of diabetic retinopathy. ${ }^{9}$ In an attempt to get further information on some of the factors in the changes in calcium and magnesium homeostasis we studied the effects on some indices of mineral metabolism of improving glycaemic control in type II diabetic patients given either metformnin or glipizide.

\section{Patients and methods}

The patients selected were all type II diabetics who had failed to respond to treatment with diet alone. Diet

Accepted for publication 7 April 1988 failure was defined as having a fasting plasma glucose of greater than $8.0 \mathrm{mmol} / 1$ on two occasions despite dietary advice. Patients were randomly allocated to treatment by either metformin (Glucophage, $0.5 \mathrm{mg}$ twice daily), or glipizide (Glibenese, $5 \mathrm{mg}$ daily). Patients were of either sex, aged 40-70 years, with a body weight not less than ideal for height and build as assessed by body mass index. ${ }^{10}$ They were not taking any other medication. Any patient with impaired hepatic or renal function was excluded.

Fasting blood samples were taken without venous stasis at entry into the study and at regular intervals for up to 24 weeks for the measurement of glucose (glucose oxidase, Technicon Instruments, New York, USA), haemoglobin $A_{1}$ (electroendosmosis, Corning Medical, Halstead, England), calcium (Cresolpthalein, SMAC, Technicon Instruments), magnesium (Magon dye)," and albumin (BCG, SMAC, Technicon Instruments). Fasting urine collections (three hours) were also made at the beginning of the study and at 24 weeks. All collections were taken at the same time each day. Measurements of urinary calcium and magnesium were made by atomic absorption spectrophotometry and results expressed in terms of the excretion of creatinine concentration (Alkaline Picrate Technicon AA II).

Comparisons between results were made by Student's $t$ test (paired or unpaired). Correlations were assessed by linear regression analysis using the method of least squares fit.

\section{Results}

Thirty four patients completed the study, 14 in the 
metformin group and 20 in the glipizide group. There were no significant differences between the groups at the outset in any of the variables measured (table 1). Twelve $(35 \%)$ of the patients were hypomagnesaemic compared with the reference range (0.70-1.00 mmol/ 1), but the serum magnesium concentration did not relate to either the glucose or haemoglobin $A_{1}$ concentrations.

The figure shows the changes in the concentrations of the analytes over the following six months. The two groups showed parallel improvement in glycaemic control as measured by fasting glucose and haemoglobin $\mathbf{A}_{1}$. This improvement was not reflected in any change in serum calcium concentration, but there was a clear and highly significant difference in the effects on serum magnesium concentration. Despite the improved control, patients receiving metformin showed no change in serum magnesium concentration. In contrast, the patients receiving glipizide showed a significant increase in magnesium from the basal values ( $p<0.001$, paired $t$ test). At 24 weeks seven $(50 \%)$ of the patients receiving metformin $(50 \%)$ were hypomagnesaemic $(<0.70 \mathrm{mmol} / \mathrm{l}) \mathrm{com}$ pared with only three $(15 \%)$ of those receiving glipizide.

Further evidence of differences in the handling of magnesium between the two treatment groups comes from the fasting urinary excretion measurements (table 2). The improved glycaemic control was not reflected in a significant reduction in calcium excretion in patients of either group nor was there a reduction in magnesium excretion in patients receiving glipizide. In contrast, the patients receiving metformin showed a pronounced reduction in magnesium excretion, all except one showing an excretion below our upper limit for young laboratory workers $(0.32 \mathrm{mmol} / \mathrm{mmol})$. There was no association between calcium or magnesium excretion and blood glucose even at the start of the study. There was a significant correlation before

Table 1 Basic information on 34 diabetics before treatment with glipizide or metformin (Values are given as mean (SEM) where appropriate)

\begin{tabular}{|c|c|c|}
\hline & $\begin{array}{l}\text { Glipizide group } \\
(n=20)\end{array}$ & $\begin{array}{l}\text { Metformin group } \\
(n=14)\end{array}$ \\
\hline $\begin{array}{l}\text { Age (years) } \\
\text { Sex }\end{array}$ & $\begin{array}{l}56 \cdot 3(2 \cdot 0) \\
7 \mathrm{M} 13 \mathrm{~F}\end{array}$ & $\begin{array}{l}56 \cdot 5(2 \cdot 8) \\
5 \mathrm{M} 9 \mathrm{~F}\end{array}$ \\
\hline $\begin{array}{l}\text { Body mass index } \\
\left(19-24.9 \mathrm{~kg} / \mathrm{m}^{2}\right)\end{array}$ & $29.8(1 \cdot 5)$ & $29 \cdot 6(1 \cdot 2)$ \\
\hline $\begin{array}{l}\text { Plasma glucose } \\
(3 \cdot 3-6 \cdot 1 \mathrm{mmol} / 1)\end{array}$ & $12.25(0.78)$ & $11.01(0.87)$ \\
\hline $\begin{array}{l}\text { Haemoglobin } A_{1} \\
(5.6-9.0 \%)\end{array}$ & $11.88(0.52)$ & $11.49(0.50)$ \\
\hline $\begin{array}{l}\text { Serum magnesium } \\
(0.70-1.00 \mathrm{mmol} / \mathrm{l})\end{array}$ & $0.727(0.013)$ & $0.713(0.011)$ \\
\hline $\begin{array}{l}\text { Serum calcium } \\
(2.15-2.70 \mathrm{mmol} / \mathrm{l})\end{array}$ & $2.304(0.015)$ & $2.304(0.018)$ \\
\hline $\begin{array}{l}\text { Serum albumin } \\
\quad(38-50 \mathrm{~g} / \mathrm{l})\end{array}$ & $44.8(0.5)$ & $43.6(0.6)$ \\
\hline
\end{tabular}

treatment started, however, between the haemoglobin $A_{1}$ concentration and the urinary calcium:creatinine ratio $(r=0.396, p<0.02)$. In these poorly controlled diabetics the calcium and magnesium excretion were
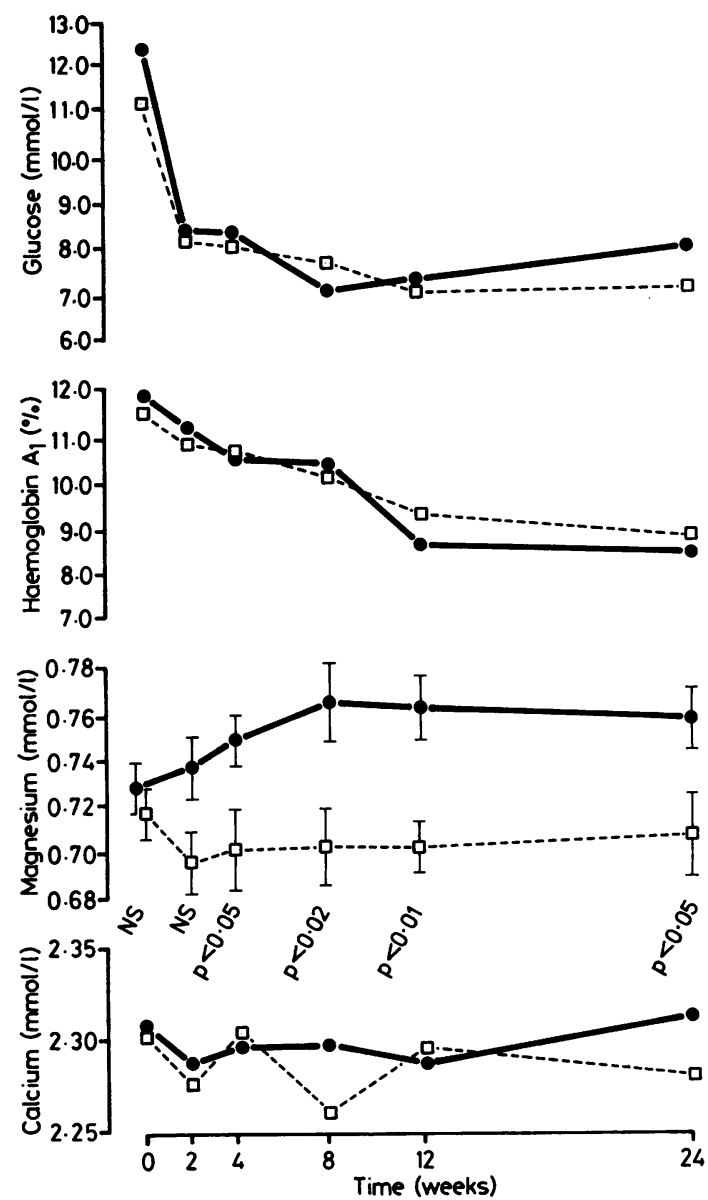

Figure Mean (SEM) for haemoglobin $A_{1}$, plasma glucose, and serum calcium and magnesium concentrations in 34 patients randomly allocated to treatment with either glipizide (○-O) or metformin ( $\square-\square$ ).

Table 2 Mean (SEM) urinary calcium and magnesium excretion before and after 24 weeks of treatment with either glipizide or metformin

\begin{tabular}{|c|c|c|c|}
\hline & & $\begin{array}{l}\text { Magnesium: creatinine } \\
(\mathrm{mmol} / \mathrm{mmol})\end{array}$ & $\begin{array}{l}\text { Calcium: creatinine } \\
\text { (mmol/mmol) }\end{array}$ \\
\hline $\begin{array}{l}\text { Glipizide } \\
(\mathrm{n}=20)\end{array}$ & $\begin{array}{r}0 \text { weeks } \\
24 \text { weeks }\end{array}$ & $\begin{array}{l}0.276(0.029) \\
0.264(0.027)\end{array}$ & $\begin{array}{l}0.453(0.062) \\
0.414(0.050)\end{array}$ \\
\hline $\begin{array}{l}\text { Metformin } \\
(n=14)\end{array}$ & $\begin{array}{r}0 \text { weeks } \\
24 \text { weeks }\end{array}$ & $\begin{array}{l}0.320(0.042) \\
0.172(0.025)^{*}\end{array}$ & $\begin{array}{l}0.414(0.061) \\
0.340(0.056)\end{array}$ \\
\hline
\end{tabular}

Difference from 0 weeks, $\mathrm{p}<0.001$ (paired $t$ test)

*Difference from glipizide group, $p<0.02$. 
related $(r=0.494, p<0.01)$. After 24 weeks of improved control this association was still found in the group receiving glipizide $(r=0.581, p<0.01)$ but not in the other group.

\section{Discussion}

This randomised longitudinal study of type II diabetics treated with either metformin or glipizide shows that there is a difference in magnesium homeostasis between the two groups. This difference does not seem to be related to glycaemic control. Fasting blood glucose and haemoglobin $A_{1}$ concentrations were the same in both groups at each stage of the study; and even at the outset, when the patients were poorly controlled, neither the serum nor urinary magnesium concentration correlated with the fasting blood glucose concentration. This contrasts with the observations made by some other workers ${ }^{312}$ when hypomagnesaemia and hypermagnesuria were found to be related to hyperglycaemia and glycosuria. These studies, however, were either performed on insulin dependent diabetics ${ }^{3}$ or in mixed type I and type II populations. ${ }^{12}$

The relative hypomagnesaemia of patients receiving metformin confirms an association with biguanide treatment (phenformin) reported earlier. ${ }^{5}$ It was not accompanied by excessive urinary losses of magnesium. Indeed, unlike glipizide, metformin caused a significant fall in fasting magnesium excretion (table 2). The reasons for this are not clear but it is more in line with the usual relation between plasma and urinary magnesium ${ }^{13}$ : it is possibly of some advantage to the patients. Although metformin treatment does not correct hypomagnesaemia, it prevents excessive urinary losses of magnesium.

Insulin activity may be a factor in the way in which magnesium is handled by the two groups. An important action of the sulphonylureas such as glipizide is to increase insulin release from the pancreatic B cell. This is in contrast to the action of metformin which lowers the raised plasma insulin concentrations found in type II diabetics, ${ }^{14}$ although it enhances the activity of insulin. ${ }^{1516}$ Insulin may induce a shift of magnesium from plasma to erythrocytes which is independent of any changes in plasma glucose. ${ }^{17} 18$ A negative association was also found between fasting insulin and plasma magnesium concentrations in 55 type II diabetics, most of whom were taking sulphonylureas. ${ }^{12}$ Effects on the renal handling of magnesium have also been observed. In diabetics the urinary excretion of magnesium increased with insulin dosage, independent of glycosuria, ${ }^{9}$ and administration of insulin in normal man has been reported to produce increased excretion of magnesium. ${ }^{19}$ Thus it may be that part of the explanation for the difference in magnesium excretion between our two groups of patients lies in the release and activity of insulin.
Clearly, the control of magnesium homeostasis in type II diabetics is complex, but in view of the possible clinical importance of hypomagnesaemia, ${ }^{5}$ the differential effects of oral hypoglycaemic agents warrant further study.

The financial support of Lipha Pharmaceuticals Limited for some of the assays is acknowledged.

\section{References}

1 Raskin P, Stevenson MRM, Barilla DE, Pak CY. The hypercalciuria of diabetes mellitus: its amelioration with insulin. Clin Endocrinol 1978;9:329-35.

2 Levin ME, Brisseau VC, Avioli LV. Effects of diabetes mellitus on bone mass in juvenile and adult-onset diabetes. $N$ Eng $\mathrm{J} \mathrm{Med}$ 1976;294:241-5.

3 McNair P, Christensen MS, Christensen C, Madsab S, Transbol IB. Renal hypomagnesaemia in human diabetes mellitus-its relation to glucose homeostasis. Eur J Clin Invest 1982;12:81-5.

4 Hough S, Avioli AV. Alterations of bone and mineral metabolism in diabetes. In: Nattrass M, Santiago JV, eds. Recent advances in diabetes. 1984;223-9.

5 Mather HM, Nisbet JA, Burton GH et al. Hypomagnesaemia in diabetes. Clin Chim Acta 1979;95:235-42.

6 Stutzman FL, Amatuzio DS. Blood serum magnesium in portal cirrhosis and diabetes mellitus. J Lab Clin Med 1953;41:215-19.

7 Jackson CE, Meier DW. Routine serum magnesium analysis: correlation with clinical state in 5,100 patients. Ann Intern Med 1968;69:743-8.

8 Levin GE, Mather HM, Pilkington TRE. Tissue magnesium status in diabetes mellitus. Diabetologia 1981;21:131-4.

9 McNair P, Christiansen C, Madsbad S et al. Hypomagnesaemia, a risk factor in diabetic retinopathy. Diabetes 1978;27:1075-7.

10 Llewellyn-Jones D, Abraham SF. Quetelet index in diagnosis of anorexia nervosa. $\mathrm{Br}$ Med J 1984;288:1800.

11 Forbes A, Brown IRF, McBain A. $\mathbf{M g}^{2+}$ determined with a commercial kit and the Technicon RA 1000 analyser. Clin Chem 1985;31:1570.

12 Yajnik CS, Smith RF, Hockaday TDR, Ward NI. Fasting plasma magnesium concentrations and glucose disposal in diabetes. $\mathrm{Br}$ Med J 1984;288:1032-4.

13 Nordin BEC. Plasma calcium and magnesium homeostasis. In: Nordin BEC ed. Calcium, phosphate and magnesium metabolism. Edinburgh; Churchill Livingstone, 1976:208-16.

14 Nattrass M, Todd PG, Hinks L, Alberti KGMM. Comparative effects of phenformin, metformin and glibenclamide on metabolic rhythms in maturity-onset diabetics. Diabetologia 1977;13:145-52.

15 Sterne J, Junien JL. Metformin: pharmacological mechanisms of the antidiabetic and antilipidic effects and clinical consequences. In: Kuy AV, Hulst SGT, eds. Biguanide therapy today. London: Royal Society of Medicine International Congress and Symposium Series, 1981:3-13.

16 Hermann LS. Metabolic effects of metformin in relation to clinical effects and side-effects. In: Kuy AV, Hulst SGT eds. Biguanide therapy today. London: Royal Society of Medicine International Congress and Symposium Series, 1981:17-45.

17 Ratzman GW. On the insulin effect on the magnesium homeostasis. Exp Clin Endocrinol 1985;86:141-5.

18 Paolisso G, Sgambato S, Passariello $\mathrm{N}$ et al. Insulin induces opposite changes in plasma and erythrocyte magnesium concentrations in normal man. Diabetologia 1986;29:644-7.

19 Lindemann RD, Adler S, Yiengst MJ, Beard ES. Influence of various nutrients on urinary divalent cation excretion. $J \mathbf{L a b}$ Clin Med 1987;70:236-45.

Requests for reprints to: A M McBain, Department of Clinical Chemistry, Fife Area Laboratory, Hayfield Road, Kirkaldy KY2 5AG, Scotland. 